Tropical Journal of Pharmaceutical Research March 2017; 16 (3): 597-604

ISSN: $1596-5996$ (print); 1596-9827 (electronic)

(C) Pharmacotherapy Group, Faculty of Pharmacy, University of Benin, Benin City, 300001 Nigeria.

All rights reserved.

Available online at http://www.tjpr.org

Original Research Article

http://dx.doi.org/10.4314/tjpr.v16i3.14

\title{
Phytochemical screening, cytotoxicity and acute toxicity of Annona vepretorum Mart (Annonaceae) leaf extracts
}

\author{
Mariana G e Silva ${ }^{1}$, Ana P de Oliveira ${ }^{1}$, Camila de S Araújo ${ }^{1}$, Érica M de Lavor ${ }^{1}$, \\ Juliane C Silva ${ }^{1}$, Rosemairy $\mathbf{L}$ Mendes $^{2}$, Cláudia do O Pessoa ${ }^{3}$, Marcília P \\ Costa $^{4}$ and Jackson R G da S Almeida ${ }^{1}$ \\ ${ }^{1}$ Núcleo de Estudos e Pesquisas de Plantas Medicinais (NEPLAME), ${ }^{2}$ Colegiado de Ciências Farmacêuticas, Universidade \\ Federal do Vale do São Francisco, 56.304-205, Petrolina, Pernambuco, ${ }^{3}$ Universidade Federal do Ceará, 60.430-270, \\ Fortaleza, Ceará, ${ }^{4}$ Universidade Federal do Piauí, 64.049-550, Teresina, Piauí, Brazil
}

*For correspondence: Email: jackson.guedes@univasf.edu.br; Tel/Fax: +55-87-21016796

Received: 22 January 2016

Revised accepted: 9 February 2017

\begin{abstract}
Purpose: To investigate the phytochemistry, cytotoxicity and acute toxicity of leaf extracts from Annona vepretorum.

Methods: The crude extracts were obtained by maceration with hexane and methanol. The crude methanol extract was suspended in a 3:7 ( $/ \mathrm{v})$ mixture of methanol $(\mathrm{MeOH})$ and water $\left(\mathrm{H}_{2} \mathrm{O}\right)$ and partitioned with hexane, chloroform $\left(\mathrm{CHCl}_{3}\right)$ and ethyl acetate (AcOEt) in ascending order of polarity to obtain the respective extracts. In the investigation of phytochemical profile, the extracts were evaluated on thin layer chromatography (TLC) plates of silica gel. Cytotoxicity was tested using 3-(4,5-dimethyl-2thiazolyl)-2,5-diphenyl-2H-tetrazolium bromide (MTT) and (3-(4,5-dimethylthiazol-2-yl)-5-(3carboxymethoxyphenyl)-2-(4-sulfophenyl)-2H-tetrazolium) (MTS) assays against tumor cell lines, viz, HCT-116 (colon), SF-295 (brain), HL-60 (leukemic) and Sarcoma-180. Acute toxicity study was performed by administration of a single oral dose of $2 \mathrm{~g} / \mathrm{kg}$ body weight of the extracts to mice and the animals were observed for 14 days.

Results: Phytochemical screening results showed that $A$. vepretorum extracts contain alkaloids, flavonoids and terpenes. Methanol and chloroform extracts exhibited high cytotoxic activity against HCT-116, HL-60 and Sarcoma-180. Moreover, the extracts displayed low toxicity in mice, as no deaths and pronounced toxic effects were observed.

Conclusion: A. vepretorum contains a variety of secondary metabolites which may confer on this species high cytotoxic activity. In addition, the oral administration of the extracts produced low toxicity in mice.
\end{abstract}

Keywords: Annonaceae, Annona vepretorum, Phytochemistry, Tumor cell lines, Acute toxicity

Tropical Journal of Pharmaceutical Research is indexed by Science Citation Index (SciSearch), Scopus, International Pharmaceutical Abstract, Chemical Abstracts, Embase, Index Copernicus, EBSCO, African Index Medicus, JournalSeek, Journal Citation Reports/Science Edition, Directory of Open Access Journals (DOAJ), African Journal Online, Bioline International, Open-J-Gate and Pharmacy Abstracts

\section{INTRODUCTION}

The Annonaceae family comprises about 2300 2500 species and over 130 genera distributed mainly in the tropical and subtropical regions $[1,2]$. In Brazil there are about 29 genera and about 260 species, the majority occurring in forests, with few representatives in open areas
[3]. This family is characterized by the presence of terpenoids (mainly diterpenes), alkaloids (particularly isoquinoline derivatives) and essential oils with predominant composition of monoterpenes and sesquiterpenes [4,5]. Another class of substances found in this family is the acetogenins of Annonaceae, which have many 
biological activities, and one of the most important is the antitumor activity [6].

The genus Annona L. comprises approximately 175 species of trees and shrubs [7]. It has geographical distribution in Brazil where there are about 81 species of which 24 are endemic and occur in regions like the Amazon, Caatinga, Cerrado, Atlantic Forest and Pantanal [8]. This genus has great economic importance because of their edible fruits and it has been heavily researched due to the isolation and characterization of several classes of substances with important pharmacological properties such as cytotoxic, antitumor, pesticide, vermicide, antimicrobial, immunosuppressive, anti-emetic, inhibiting appetite and antimalarial $[4,9]$. Annona vepretorum Mart. is an endemic species of Brazil (Caatinga biome) and is popularly known as "pinha da Caatinga" [8]. Its fruits are an important source of nutrition, being consumed raw or in the form of juices. Its roots have popular medicinal indication to bite of bees and snakes, inflammation and pain, while the leaves are used in bath to allergies, skin diseases, yeast and bacterial infections [10].

Previous studies on this species demonstrated that the essential oil from the leaves of $A$. vepretorum showed trypanocidal and antifungal activity and that bicyclogermacrene, spathulenol and $\alpha$-phellandrene are the major constituents of the essential oil [11]. Another study showed the presence of spathulenol, limonene, caryophyllene oxide and $\alpha$-pinene in essential oil and a weak antioxidant activity [12]. It was reported that the ethanol extract of the leaves of A. vepretorum has sedative effect in mice without affecting motor coordination of the animals [13]. In addition, research has shown that the ethanol extract has anti-inflammatory and antinociceptive activity, which is related probably with the activation of opioid receptors and inhibition of release of mediators of the inflammatory process [14]. Antioxidant, cytotoxic and antimicrobial activities have also been reported for this plant [15].

In this paper, we carried out the phytochemical investigation and evaluation of cytotoxicity and acute toxicity of leaf extracts from Annona vepretorum.

\section{EXPERIMENTAL}

\section{Plant material}

The leaves of Annona vepretorum Mart. were collected in the city of Petrolina, State of Pernambuco, Brazil, in April 2015. The samples were identified by Prof José Alves de Siqueira Filho, from Centro de Recuperação de Áreas Degradadas da Caatinga (CRAD). A voucher specimen (\#18350) was deposited at the Herbarium Vale do São Francisco (HVASF), of the Federal University of São Francisco Valley (UNIVASF).

\section{Preparation of extracts}

A. vepretorum leaves $(1.100 \mathrm{~g})$ were dried in an air circulation oven at $40^{\circ} \mathrm{C}$ during $72 \mathrm{~h}$ and then were sprayed in a knife mill. The dried and pulverized leaves of $A$. vepretorum (412 g) were subjected to exhaustive maceration with hexane (Hex) and then with methanol $(\mathrm{MeOH})$ with renewal of the extractor fluid every $72 \mathrm{~h}$. The crude extracts were concentrated under vacuum, yielding $10 \mathrm{~g}$ of crude hexane extract (Av-HexC) and $83 \mathrm{~g}$ of crude methanol extract $(\mathrm{Av}-\mathrm{MeOH})$. A portion of the methanol extract $(80 \mathrm{~g})$ was suspended in a $3: 7(\mathrm{v} / \mathrm{v})$ mixture of methanol $(\mathrm{MeOH})$ and water $\left(\mathrm{H}_{2} \mathrm{O}\right)$ and partitioned with hexane, chloroform $\left(\mathrm{CHCl}_{3}\right)$ and ethyl acetate (AcOEt) in ascending order of polarity to obtain the respective extracts (Av-Hex $9.15 \mathrm{~g} ; \mathrm{Av}-\mathrm{CHCl}_{3}$ $4.35 \mathrm{~g}$; Av-AcOEt $5.45 \mathrm{~g}$ and $\mathrm{Av}-\mathrm{H}_{2} \mathrm{O} 40.0 \mathrm{~g}$ ).

\section{Qualitative analysis of phytochemicals}

The extracts were evaluated on thin-layer chromatography plates of silica gel $60 \mathrm{~F}_{254}$ aluminum supports, applied with a micropipette and eluted in different solvent systems as described by Wagner and Bladt [16], seeking to highlight the main groups of secondary metabolites (Table 1).

\section{Cell lines and culture}

Human tumor cell lines used, HCT-116 (colon), SF-295 (glioblastoma) and HL-60 (leukemic) were supplied by the National Cancer Institute (USA) and were cultured in RPMI 1640 medium supplemented with $10 \%$ fetal bovine serum and $1 \%$ of antibiotics, kept in oven at $37{ }^{\circ} \mathrm{C}$ and atmosphere containing $5 \% \mathrm{CO}_{2}$.

Murine tumor cell line, Sarcoma-180, were maintained in the peritoneal cavity of Swiss mice. The adult animals (90 days age, 30 - $40 \mathrm{~g}$ ) were randomly housed in appropriate cages at $22 \pm 2$ ${ }^{\circ} \mathrm{C}$ on a $12 \mathrm{~h}$ light/dark cycle (lights on at 6:00 am) with access to food and water ad libitum. For the in vitro cytotoxicity assay, the cell line were cultured in RPMI-1640 supplemented with $10 \%$ fetal bovine serum, sodium bicarbonate, $25 \mathrm{mM}$ HEPES, L-glutamine $300 \mathrm{mg} / \mathrm{L}$, gentamicin sulfate $50 \mathrm{mg} / \mathrm{L}$ and amphotericin B $2 \mathrm{mg} / \mathrm{L}$, kept in oven at $37^{\circ} \mathrm{C}$. 
Table 1: Elution systems and reagents used to characterize the main secondary metabolites in the extracts of Annona vepretorum by thin-layer chromatography

\begin{tabular}{|c|c|c|c|}
\hline Phytochemical & Elution system & Standard & Reagent \\
\hline Alkaloids & $\begin{array}{l}\text { Toluene:ethyl acetate: } \\
\text { diethylamine }(70: 20: 10, \mathrm{v} / \mathrm{v})\end{array}$ & Yohimbine & Dragendorff \\
\hline Anthocyanins & $\begin{array}{l}\text { Ethyl acetate:formic acid: } \\
\text { glacial acetic acid:water } \\
(100: 11: 11: 26, v / v)\end{array}$ & Methylene blue & Anisaldehyde sulfuric \\
\hline $\begin{array}{l}\text { Anthraquinones } \\
\text { aglycons }\end{array}$ & $\begin{array}{l}\text { Petroleum ether:ethyl } \\
\text { acetate:formic acid } \\
(75: 25: 1, \mathrm{v} / \mathrm{v})\end{array}$ & Anthraquinone & $\begin{array}{l}\text { Phosphomolybdic acid/ } \\
\text { ethanolic } \mathrm{H}_{2} \mathrm{SO}_{4} 10 \%\end{array}$ \\
\hline Flavonoids & $\begin{array}{l}\text { Ethyl acetate:formic acid: } \\
\text { glacial acetic acid:water } \\
(100: 11: 11: 26, \mathrm{v} / \mathrm{v})\end{array}$ & Quercetin & NEU \\
\hline Coumarins & $\begin{array}{l}\text { Toluene:ethyl ether: (1:1 } \\
\text { saturated with acetic acid } 10 \\
\%, v / v)\end{array}$ & Scopoletin & $10 \%$ ethanolic $\mathrm{KOH}$ \\
\hline Anthracene derivatives & $\begin{array}{l}\text { Ethyl acetate:methanol: water } \\
(100: 13.5: 10, \mathrm{v} / \mathrm{v})\end{array}$ & Aloin & $10 \%$ ethanolic $\mathrm{KOH}$ \\
\hline Lignans & $\begin{array}{l}\text { Chloroform:methanol:water } \\
(70: 30: 4, v / v)\end{array}$ & Flaxseed extract & Vanillin sulfuric \\
\hline $\begin{array}{l}\text { Monoterpenes, } \\
\text { sesquiterpenes and } \\
\text { diterpenes }\end{array}$ & $\begin{array}{l}\text { Toluene:ethyl acetate }(93: 7, \\
\text { v/v) }\end{array}$ & Thymol and carvacrol & Vanillin sulfuric \\
\hline Naphthoquinones & Toluene:formic acid $(99: 1, \mathrm{v} / \mathrm{v})$ & Lapachol & $10 \%$ ethanolic $\mathrm{KOH}$ \\
\hline Saponins & $\begin{array}{l}\text { Chloroform:acetic acid: } \\
\text { methanol:water (64:32:12:8, } \\
\mathrm{v} / \mathrm{v})\end{array}$ & Saponin & Sulfuric anisaldehyde \\
\hline Condensed tannins & $\begin{array}{l}\text { Ethyl acetate:glacial acetic } \\
\text { acid: acid formic:water } \\
(100: 11: 11: 26, \mathrm{v} / \mathrm{v})\end{array}$ & $\begin{array}{l}\text { Catechin } \\
\text { Epicatechin }\end{array}$ & Vanillin hydrochloric \\
\hline Hydrolysable tannins & $\begin{array}{l}\text { n-Butanol:acetone: Phosphate } \\
\text { buffer }(40: 50: 10, \mathrm{v} / \mathrm{v})\end{array}$ & $\begin{array}{l}\text { Gallic acid } \\
\text { Tannic acid }\end{array}$ & $\begin{array}{l}\text { Ferric ammonium sulfate } \\
(1 \%)\end{array}$ \\
\hline Triterpenes and steroids & $\begin{array}{l}\text { Toluene:chloroform: ethanol } \\
(40: 40: 10, \mathrm{v} / \mathrm{v})\end{array}$ & $\begin{array}{l}\text { Lupeol } \\
\text { Sitosterol }\end{array}$ & Liebermann-Burchard \\
\hline Xanthine & $\begin{array}{l}\text { Ethyl acetate:Methanol: Water } \\
(100: 13.5: 10, \mathrm{v} / \mathrm{v})\end{array}$ & Caffeine & lodine-KI-HCl \\
\hline
\end{tabular}

\section{Determination of cytotoxicity}

Human tumor cell lines were plated in 96-well plates: HCT-116 $\left(0.7 \times 10^{5}\right.$ cells $\left./ \mathrm{mL}\right)$, SF-295 $\left(0.1 \times 10^{6}\right.$ cells $\left./ \mathrm{mL}\right)$ and HL-60 (0.3 $\times 10^{6}$ cells $/ \mathrm{mL})$. The plates were incubated with the extracts $(50 \mu \mathrm{g} / \mathrm{mL})$ dissolved in $1 \%$ DMSO for $72 \mathrm{~h}$ in an incubator at $5 \% \mathrm{CO}_{2}$ at $37^{\circ} \mathrm{C}$. At the end of this, they were centrifuged and the supernatant removed. Thereafter, a $150 \mu \mathrm{L}$ solution of 3-(4,5-dimethyl-2-thiazolyl)-2,5diphenyl-2H-tetrazolium bromide (MTT) was added, and the plates incubated for $3 \mathrm{~h}$. After incubation, the plates were centrifuged again to remove the MTT solution. The absorbance was read after solubilization of the formazan precipitate with $150 \mu \mathrm{L}$ of pure DMSO at $595 \mathrm{~nm}$ spectrophotometer plate.

Sarcoma-180 cells maintained in vivo were added with phosphate buffer (PBS) and subsequently centrifuged (1200 rpm for $3 \mathrm{~min}$ ). The supernatant was discarded and Cells were re-suspended in RPMI-1640 medium. The cells were then seeded $\left(1 \times 10^{5}\right.$ cells/well suspended in $50 \mu \mathrm{L}$ of medium) in 96-well plates and incubated with the extracts $(50 \mu \mathrm{g} / \mathrm{mL})$ dissolved in $1 \%$ DMSO for $24 \mathrm{~h}$ at $37^{\circ} \mathrm{C}$. After $24 \mathrm{~h}, 0.02$ $\mathrm{mL}$ of 3-(4,5-dimethylthiazol-2-yl)-5-(3-carboxy methoxyphenyl)-2-(4-sulfophenyl)-2H-tetrazolium (MTS) in a concentration of $5 \mathrm{mg} / \mathrm{mL}$ was added to each well. After incubation for $3 \mathrm{~h}$, the absorbance (Abs) was read at $492 \mathrm{~nm}$ on spectrophotometer plate and the cell proliferation inhibition $(P)$ was calculated using Eq 1.

$P(\%)=100-\{(\mathrm{At} / \mathrm{Au})\} 100$

where At and Au are the absorbance of treated and untreated cells, respectively.

The concentration that caused $50 \%$ cell growth inhibition $\left(\mathrm{IC}_{50}\right)$ was determined from the concentration-response curves by non-linear regression with a confidence interval of $95 \%$. An intensity scale was used to assess the cytotoxic 
potential of the tested samples: samples without activity (SA), with weak activity (cell growth inhibition ranging from 1 to $50 \%$ ), with moderate activity (cell growth inhibition ranging from 50 to $75 \%$ ) and strong activity (cell growth inhibition ranging from 75 to $100 \%$ ).

\section{Acute toxicity test}

The acute toxicity study was performed according to OECD 423 Guidelines for testing of chemicals [17]. The mice were randomly divided into 7 groups of 3 female mice. Group I: normal control group, and the mice received vehicle (saline/0.2 \% Tween 80); Group II: $2 \mathrm{~g} / \mathrm{kg}$ body weight Av-MeOH; Group III: 2 g/kg body weight Av-HexC; Group IV: 2 g/kg body weight Av-Hex; Group V: $2 \mathrm{~g} / \mathrm{kg}$ body weight $\mathrm{Av}-\mathrm{CHCl}_{3}$; Group VI: 2 g/kg body weight Av-AcEtOH; Group VII: 2 $\mathrm{g} / \mathrm{kg}$ body weight $\mathrm{Av}-\mathrm{H}_{2} \mathrm{O}$. After administration of the extract, the animals were observed every 30 $\min$ for $4 \mathrm{~h}$ on the first day and once daily for 14 days. During this period the emergence of general toxic signs was assessed [18]. The $\mathrm{LD}_{50}$ of the extracts was investigated based on the eventual observation of mortality. The mice were assessed daily throughout the study to monitor their body weight variation, consumption of food and water. Experimental protocols and procedures were approved by the Federal University of San Francisco Valley Animal Care and Use Committee (protocol no. 0018/140415).

\section{Statistical analysis}

Statistical analysis was performed using GraphPad Prism $^{\circledR} \quad 5.0$ software. The experimental results were analyzed employing the Student's $t$ test. Data are presented as mean \pm standard deviation (SD) and differences were considered significant when $p<0.05$.

\section{RESULTS}

\section{Phytochemical profile}

The phytochemical analysis of $A$. vepretorum showed that almost all extracts, except the crude hexane extract (Av-HexC), were positive for the presence of flavonoids. The methanol, hexane, chloroform and ethyl acetate extracts also showed positive reaction for the presence of alkaloids. Only the aqueous extract was not positive for the presence of monoterpenes, sesquiterpenes, diterpenes, triterpenes and steroids. The methanol and ethyl acetate extracts were positive for anthocyanins. The chloroform and ethyl acetate extracts were positive for naphthoquinones and hydrolysable tannins. Only the ethyl acetate extract was positive for saponins. All extracts of $A$. vepretorum showed negative results for the presence of anthraquinones, anthracene derivatives, lignans, naphtoquinones, condensed tannins and xanthine. These results are presented in Table 2.

Table 2: Phytochemical profile of extracts of Annona vepretorum

\begin{tabular}{|c|c|c|c|c|c|c|}
\hline Phytochemical & Av-MeOH & Av-HexC & Av-Hex & $\mathrm{Av}-\mathrm{CHCl}_{3}$ & Av-AcOEt & $\mathrm{Av}-\mathrm{H}_{2} \mathrm{O}$ \\
\hline Alkaloids & + & - & + & ++ & + & - \\
\hline Anthocyanins & + & - & - & - & ++ & - \\
\hline $\begin{array}{l}\text { Anthraquinones } \\
\text { aglycons }\end{array}$ & - & - & - & - & - & - \\
\hline Flavonoids & ++ & - & + & +++ & ++ & ++ \\
\hline Coumarins & - & - & - & + & - & - \\
\hline Anthracene derivatives & - & - & - & - & - & - \\
\hline Lignans & - & - & - & - & - & - \\
\hline $\begin{array}{l}\text { Monoterpenes, } \\
\text { sesquiterpenes and } \\
\text { diterpenes }\end{array}$ & + & +++ & +++ & +++ & + & - \\
\hline Naphthoquinones & - & - & - & + & + & - \\
\hline Saponins & - & - & - & - & + & - \\
\hline Condensed tannins & - & - & - & - & - & - \\
\hline Hydrolysable tannins & - & - & - & + & + & - \\
\hline Triterpenes and steroids & + & +++ & + & + & + & - \\
\hline Xanthine & - & - & - & - & - & - \\
\hline
\end{tabular}

(-) Not detected; (+) low presence; (++) moderate presence; (+++) strong presence. Av-MeOH (crude methanol extract), $\mathrm{Av}$-HexC (crude hexane extract), $\mathrm{Av}$-Hex (hexane extract), $\mathrm{Av}$ - $\mathrm{CHCl}_{3}$ (chloroform extract), $\mathrm{Av}$ - $\mathrm{AcOEt}$ (ethyl acetate extract), $\mathrm{Av}-\mathrm{H}_{2} \mathrm{O}$ (aqueous extract)

\section{Cytotoxicity}

The methanol and chloroform extracts showed a high cytotoxic potential in three of the tested lines
(HCT-116, HL-60 and Sarcoma-180). The crude hexane extract had a high cytotoxic potential in glioblastoma line (SF-295) and Sarcoma-180. The hexane partition and aqueous extracts 
showed high cytotoxic activity only in sarcoma180 cell line. The ethyl acetate extract had an activity ranging from low to moderate in cell lines (Table 3).

\section{Acute toxicity}

In the evaluation of the acute toxicity of extracts obtained from the leaves of $A$. vepretorum there was no death or signs of toxicity in any of the groups that received a single dose of extract and were assessed for 14 days of the experiment. The animal treated with the extracts showed some significant changes in body weight when compared with the control group (Table 4). The results for evaluation of acute toxicity are presented in Table 4, Table 5 and Table 6, and represent the mean values obtained in the first and in the last 7 days as well as the mean values after 14 days.

Table 3: Cell proliferation inhibition (\%) of extracts of Annona vepretorum (50 $\mu \mathrm{g} / \mathrm{mL})$

\begin{tabular}{lccccc}
\hline Extract & \multicolumn{3}{c}{ Cell proliferation inhibition (\%) } & IC $_{\mathbf{5 0}}(\boldsymbol{\mu g} / \mathbf{m L})$ \\
\cline { 2 - 6 } & $\boldsymbol{H C T}-\mathbf{1 1 6}$ & SF-295 & $\boldsymbol{H L}-\mathbf{6 0}$ & Sarcoma-180 & \\
\hline $\mathrm{Av}-\mathrm{MeOH}$ & $98.16 \pm 0.92$ & $63.98 \pm 3.40$ & $82.23 \pm 4.84$ & $82.34 \pm 1.36$ & $2.81 \pm 0.41$ \\
$\mathrm{Av}-\mathrm{HexC}$ & $29.96 \pm 1.60$ & $86.54 \pm 3.31$ & $17.11 \pm 7.34$ & $79.43 \pm 4.39$ & $4.87 \pm 0.83$ \\
$\mathrm{Av}-\mathrm{Hex}$ & $56.04 \pm 21.00$ & $65.43 \pm 6.52$ & $55.85 \pm 3.56$ & $86.24 \pm 1.09$ & $45.82 \pm 9.07$ \\
$\mathrm{Av}-\mathrm{CHCl}$ & $74.28 \pm 0.25$ & $82.05 \pm 24.67$ & $29.79 \pm 1.82$ & $81.32 \pm 6.79$ & $2.88 \pm 1.39$ \\
$\mathrm{Av}-\mathrm{AcOEt}$ & $17.87 \pm 6.45$ & $27.98 \pm 5.16$ & $68.72 \pm 38.28$ & $63.15 \pm 6.57$ & $22.82 \pm 3.76$ \\
$\mathrm{Av}-\mathrm{H}_{2} \mathrm{O}$ & $9.52 \pm 11.68$ & $6,72 \pm 1.25$ & $-8.20 \pm 3.33$ & $78.57 \pm 5.91$ & $71.18 \pm 1,69$ \\
\hline
\end{tabular}

HCT-116 (colon), SF-295 (brain), HL-60 (leukemia). Values are mean \pm SD $(n=3) ; 95 \%$ confidence intervals

Table 4: Mice weight after administration of a single dose of different extracts of $A$. vepretorum $(2 \mathrm{~g} / \mathrm{kg})$

\begin{tabular}{lccc}
\hline \multirow{2}{*}{ Group } & \multicolumn{3}{c}{ Animal weight (g) } \\
\cline { 2 - 4 } & $\mathbf{1 - 7}$ days & $\mathbf{8 - 1 4 \text { days }}$ & $\mathbf{1 4 ~ d a y s}$ \\
\hline Control & $32.19 \pm 0.37$ & $32.14 \pm 0.32$ & $32.17 \pm 0.33$ \\
$\mathrm{Av}-\mathrm{MeOH}$ & $32.95 \pm 0.44^{*}$ & $32.33 \pm 0.38$ & $32.64 \pm 0.51^{*}$ \\
$\mathrm{Av}-\mathrm{HexC}$ & $29.71 \pm 0.48^{*}$ & $29.00 \pm 0.43^{*}$ & $29.36 \pm 0.57^{*}$ \\
$\mathrm{Av}-\mathrm{Hex}$ & $31.10 \pm 0.41^{*}$ & $30.67 \pm 0.67^{*}$ & $30.88 \pm 0.48^{*}$ \\
$\mathrm{Av}-\mathrm{CHCl}$ & $30.33 \pm 0.33^{*}$ & $30.29 \pm 0.35^{*}$ & $30.31 \pm 0.33^{*}$ \\
$\mathrm{Av}-\mathrm{AcOEt}$ & $30.95 \pm 0.23^{*}$ & $31.24 \pm 0.49^{*}$ & $31.10 \pm 0.40^{*}$ \\
$\mathrm{Av}-\mathrm{H}_{2} \mathrm{O}$ & $28.76 \pm 0.49^{*}$ & $28.86 \pm 0.46^{*}$ & $28.81 \pm 0.46^{*}$ \\
\hline
\end{tabular}

Values are mean $\pm \mathrm{SD} ;{ }^{*} p<0.05$

Table 5: Water consumption after administration of a single dose of different extracts of $A$. vepretorum (2 $\mathrm{g} / \mathrm{kg})$

\begin{tabular}{lccc}
\hline \multirow{2}{*}{ Group } & \multicolumn{3}{c}{ Water consumption $(\mathbf{m L})$} \\
\cline { 2 - 4 } & $\mathbf{1 - 7}$ days & $\mathbf{8 - 1 4}$ days & 14 days \\
\hline Control & $22.57 \pm 2.14$ & $20.71 \pm 2.49$ & $21.64 \pm 2.43$ \\
$\mathrm{Av}-\mathrm{MeOH}$ & $25.43 \pm 1.90^{*}$ & $26.86 \pm 3.80^{*}$ & $26.14 \pm 2.98^{\star}$ \\
$\mathrm{Av}-\mathrm{HexC}$ & $26.57 \pm 5.12$ & $27.57 \pm 1.13^{\star}$ & $27.07 \pm 3.60^{*}$ \\
$\mathrm{Av}-\mathrm{Hex}$ & $29.29 \pm 10.01$ & $37.14 \pm 3.43^{*}$ & $33.21 \pm 8.26^{*}$ \\
$\mathrm{Av}-\mathrm{CHCl}$ & $33.71 \pm 8.90^{*}$ & $30.86 \pm 6.09^{*}$ & $32.29 \pm 7.47^{\star}$ \\
$\mathrm{Av}-\mathrm{AcOEt}$ & $26.57 \pm 8.14$ & $24.29 \pm 1.79^{*}$ & $25.43 \pm 5.78^{*}$ \\
$\mathrm{Av}-\mathrm{H}_{2} \mathrm{O}$ & $30.29 \pm 13.68$ & $32.14 \pm 5.61^{*}$ & $31.21 \pm 10.09^{*}$ \\
\hline
\end{tabular}

Values are mean $\pm \mathrm{SD} ;{ }^{*} p<0.05$

Table 6: Feed consumption after administration of a single dose of different extracts of $A$. vepretorum (2 g/kg body weight)

\begin{tabular}{lccc}
\hline \multirow{2}{*}{ Group } & \multicolumn{3}{c}{ Food consumption $(\mathbf{m L})$} \\
\cline { 2 - 4 } & $\mathbf{1 - 7}$ days & $\mathbf{8 - 1 4 \text { days }}$ & $\mathbf{1 4}$ days \\
\hline Control & $15.00 \pm 1.63$ & $15.43 \pm 1.13$ & $15.21 \pm 1.36$ \\
$\mathrm{~A} v-\mathrm{MeOH}$ & $16.57 \pm 1.39$ & $16.43 \pm 1.71$ & $16.50 \pm 1.50^{\star}$ \\
$\mathrm{Av}-\mathrm{HexC}$ & $13.71 \pm 1.38$ & $14.71 \pm 0.95$ & $14.21 \pm 1.25$ \\
$\mathrm{Av}-\mathrm{Hex}$ & $14.71 \pm 2.62$ & $16.86 \pm 2.19$ & $15.79 \pm 2.57$ \\
$\mathrm{Av}-\mathrm{CHCl}$ & $14.00 \pm 1.29$ & $15.57 \pm 1.13$ & $14.79 \pm 1.42$ \\
$\mathrm{Av}-\mathrm{AcOEt}$ & $15.00 \pm 1.41$ & $15.57 \pm 2.14$ & $15.29 \pm 1.77$ \\
$\mathrm{Av}-\mathrm{H}_{2} \mathrm{O}$ & $13.86 \pm 2.03$ & $16.14 \pm 2.26$ & $15.00 \pm 2.38$ \\
\hline
\end{tabular}

Values are mean $\pm \mathrm{SD} ;{ }^{*} p<0.05$ 
Water consumption was increased in the treated groups compared to the control (Table 5). As well as for the feed intake, there was only increased consumption in the group treated with the methanol extract when we calculate the average consumption for 14 days of evaluation (Table 6).

\section{DISCUSSION}

Investigations about the chemical composition of plants of Caatinga that are traditionally used to treat various diseases had identified secondary metabolites with promising pharmacological activities [13]. Phytochemical analysis showed the presence of flavonoids, except in crude hexane extract (Av-HexC), confirming previous studies with $A$. vepretorum [15]. A large number of biological activities have been attributed to these compounds, including anticancer activity [19]. It was also demonstrated the presence of alkaloids and terpenes in the extracts [4].

MTT assay is a well-known colorimetric assay that is based on the enzymatic reduction of the tetrazolium salt MTT to a formazan product in viable cells. It has been largely used to determine cytostatic/cytotoxic potential of medicinal agents in screening programs [20]. The MTS assay has the same general principle of MTT test. Those extracts that caused more than $75 \%$ cell growth inhibition in any cell line were considered active. Thus, only the methanol extract and chloroform extract showed strong activity against human tumor cell lines. On Sarcoma-180, the extracts showed strong activity, but the ethyl acetate extract showed moderate activity.

According to the American National Cancer Institute, the $\mathrm{IC}_{50}$ threshold for considering a promising extract for cancer treatment should be less than $50 \mu \mathrm{g} / \mathrm{mL}$ [21]. Thus, the methanol extract, crude hexane extract, partitioned hexane extract, chloroform and ethyl acetate presented promising results based on the $\mathrm{IC}_{50}$ values, which could be attributed to the presence of alkaloids, flavonoids and terpenes, since these classes of secondary metabolites have cytotoxic activity [22-24].

The majority $(60 \%)$ of anticancer drugs introduced into therapy has its origin in natural products, however, most chemotherapeutic drugs used in clinical practice are not selective for tumor cells, causing severe side effects. Thus, it is critical to characterize the toxicity profile of potential candidates for antitumor agents [25]. It was observed that a single oral administration of $2 \mathrm{~g} / \mathrm{kg}$ body weight extracts of
A. vepretorum leaves did not cause any mortality or alteration in behavioural or physiological state of animals indicating that the plant extracts are not toxic at the tested dose and that its $L D_{50}$ is likely to be greater than $2 \mathrm{~g} / \mathrm{kg}$.

Analysis of the body weight (Table 4) of treated animals with the extracts showed some differences when compared with the control. However, there was no marked weight loss of animals over the 14 days of evaluation. Generally, changes in these parameters reflect its toxic effects, especially if such loss is greater than $10 \%$ of the initial weight [26].

The analysis of the ingestion of food and water is an important parameter to investigate the safety of the substances studied for therapeutic purpose, particularly for substances which exhibit indicative of gastrointestinal toxicity, which may cause decreased intake of feed and water, and hence weight loss [27]. In contrast, there was an increase of water consumption in the treated groups compared with the control. As well as for the feed intake, there was only a statistically significant increase in consumption in the group treated with methanol extract compared to the control, demonstrating the low toxicity of the extracts.

\section{CONCLUSION}

A. vepretorum contains a variety of secondary metabolites which may confer on this species the capacity to inhibit the growth of human tumor cell lines and sarcoma-180 in vitro. Moreover, the administration of a single dose of the extracts shows low toxicity in mice. Thus, $A$. vepretorum is a potential source of bioactive compounds with cytotoxic activity and low oral toxicity, which should be further investigated in the search for new molecules with potential anticancer activity.

\section{DECLARATIONS}

\section{Acknowledgement}

The authors thank Brazilian National Agencies CAPES, CNPq, FACEPE and FUNCAPE for financial support for the work.

\section{Conflict of Interest}

No conflict of interest associated with this work.

\section{Contribution of Authors}

The authors declare that this work was done by 
the authors named in this article and all liabilities pertaining to claims relating to the content of this article will be borne by them.

\section{Open Access}

This is an Open Access article that uses a funding model which does not charge readers or their institutions for access and distributed under the terms of the Creative Commons Attribution License (http://creativecommons.org/licenses/by 14.0) and the Budapest Open Access Initiative (http://www.budapestopenaccessinitiative.org/rea d), which permit unrestricted use, distribution, and reproduction in any medium, provided the original work is properly credited.

\section{REFERENCES}

1. Carballo Al, Martínez AL, González-trujano E, Pellicer $F$, Ventura-martínez R, Díaz- reval MI, López-Muñoz FJ. Antinociceptive activity of Annona diversifolia Saff. leaf extracts and palmitone as a bioactive compound. Pharmacol Biochem Behav 2010; 95: 6-12.

2. Heywood VH. Flowering plants of the world. Oxford University Press: Oxford, 1985.

3. Maas PJM, Kamer HM, Junikka L, Mello-Silva RD, Rainer H. Annonaceae from Central-eastern Brazil. Rodriguésia 2001; 52: 65-98.

4. Leboeuf $M$, Cavé A, Bhaumik PK, Mukherjee B, Mukherjee R. The phytochemistry of the Annonaceae. Phytochemistry 1982; 21: 2783-2813.

5. Silva MS, Tavares JF, Queiroga KF, Agra MF, BarbosaFilho JM, Almeida JRGS, Silva SAS. Alkaloids and other constituents from Xylopia langsdorffiana (Annonaceae). Quím Nova 2009; 32: 1566-1570.

6. Nascimento $F C$, Boaventura MAD, Assunção ACS, Pimenta LPS. Acetogeninas de anonáceas isoladas de folhas de Rollinia laurifolia. Quím Nova 2003; 26: 319322.

7. Dutra LM, Costa EV, Moraes VRS, Nogueira PCL, Vendramin ME, Barison A, Prata APN. Chemical constituents from the leaves of Annona pickelii (Annonaceae). Biochem Syst Ecol 2012; 41: 115-118.

8. Maas $P$, Lobão A, Rainer $H$. Annonaceae in Lista de Espécies da Flora do Brasil. Jardim Botânico do Rio de Janeiro. [updated 2015 Jan 23; cited 2015 Nov 23]. Available from:http://floradobrasil.jbrj.gov.br/jabot/florado brasil/FB110235

9. Santos TG, Rebelo RA, Dalmarco EM, Guedes $A$, Gasper AL, Cruz AB, Schimit AP, Cruz RCB, Steindel $M$, Nunes RK. Chemical composition and antimicrobial activity of leaf essential oil from Piper malacophyllum (C. Presl.) C. DC. Quím Nova 2012; 35: 477-481.

10. Dutra $L M$, Bomfim $L M$, Rocha SLA, Nepel A, Soares $M B P$, Barison A, Costa EV, Bezerra DP. ent-Kaurane diterpenes from the stem bark of Annona vepretorum
(Annonaceae) and cytotoxic evaluation. Bioorg. Med. Chem. Lett. 2014; 24: 3315-3320.

11. Costa EV, Dutra LM, Nogueira PCL, Moraes VRS, Salvador MJ, Ribeiro LHG, Gadelha FR. Essential oil from the leaves of Annona vepretorum: chemical composition and bioactivity. Nat Prod Commun. 2012; 7: 265-266.

12. Araújo CS, Oliveira $A P$, Lima $R N$, Alves $P B$, Diniz TC, Almeida JRGS. Chemical constituents and antioxidant activity of the essential oil from leaves of Annona vepretorum Mart. (Annonaceae). Pharmacogn Mag 2015; 43: 616-618.

13. Diniz TC, Araújo CS, Silva JC, Oliveira-Júnior RG, LimaSaraiva SRG, Quintans-Júnior LJ, Nunes XP, Almeida JRGSJ. Phytochemical screening and central nervous system effects of ethanolic extract of Annona vepretorum (Annonaceae) in mice. J. Med. Plant Res. 2013, 7, 2729.

14. Silva JC, Araújo CS, Lima-Saraiva SRG, Oliveira Junior RG, Diniz TC, Wanderley CWS, Palheta-Júnior RC, Mendes RL, Guimaraes AG, Quintans-Junior LJ, Almeida JRGS. Antinociceptive and anti-inflammatory activities of the ethanolic extract of Annona vepretorum Mart. (Annonaceae) in rodents. BMC Complementary and Alternative Medicine (Online) 2015; 15: 1-10.

15. Almeida JRGS, Araújo CS, Pessoa CO, Costa MP, Pacheco AGM. Atividade antioxidante, citotóxica e antimicrobiana de Annona vepretorum Mart. (Annonaceae). Rev Bras Frutic 2014; 36: 258-264.

16. Wagner H, Bladt S. Plant drug analysis: a thin layer chromatography atlas. Berlim Heidelberg: Springer Verlag. 1996: 384.

17. Organization for Economic Cooperation and Development (OECD). OECD guidelines for testing of chemicals - Acute Oral Toxicity methods. No. 423, 2001: 1-13.

18. Almeida RN, Falcão ACGM, Diniz RST, Quintans-Júnior LJ, Polari RN, Barbosa-Filho JM, Agra MF, Duarte JC, Ferreira CD, Antoniolli AR, Araújo CC. Metodologia para avaliação de plantas com atividade no sistema nervoso central e alguns dados experimentais. Rev Bras Farm 1999; 80: 72-76.

19. VEGA, Maria R. G. et al. Flavonoids from Annona dioica leaves and their effects in Ehrlich carcinoma cells, DNAtopoisomerase I and II. J. Braz. Chem. Soc. 2007;18: 1554-1559.

20. Sandra SR, Aline MJ, Charlene SA, Thanany BS, Alan DCS, Jemmyson RJ, Moacir SA, Tais SS, Wesley FG, Péricles BA, et al. Evaluation of the Cytotoxic Activity of Some Brazilian Medicinal Plants. Planta Med. 2012; 78: 1601-1606.

21. Renzi $D$, Valtolina $M$, Foster $R$. The evaluation of a multiendpoint cytotoxicity assay system. ATLA-Altern. Lab. Anim. 1993; 21: 89-96.

22. Vila-Nova, N. S. Leishmanicidal activity and cytotoxicity of compounds from two Annonaceae species cultivated in Northeastern Brazil. Rev. Soc. Bras. Med. Trop. 2011; 44: 567-571.

Trop J Pharm Res, March 2017; 16(3): 603 
23. Katrin S. Cytotoxicity of dietary flavonoids on different human cancer types. Pharmacogn Rev. 2014; 8: 122146.

24. Mathabe MC, Hussein AA, Nikolova RV, Basson $A E$, Meyer JJ, Lall N. Antibacterial activities and cytotoxicity of terpenoids isolated from Spirostachys africana. $J$ Ethnopharmacol. 2008; 116: 194-197.

25. Mondal S, Bandyopadhyay S, Ghosh MK, Mukhopadhyay S, Roy S, Mandal C. Natural products: promising resources for cancer drug discovery Anticancer Agents. Med Chem. 2012; 12: 49-75.

26. Subramanion LJ, Zuraini Z, Yeng C, Yee LL, Lachimanan $Y L$, Sreenivasan, S. Acute oral toxicity of methanolic seed extract of Cassia fistula in mice. Molecules 2011; 16: 5268-5282.

27. Mukinda JT, Eagles PFK. Acute and subchronic oral toxicity profiles of the aqueous extract of Polygala fruticosa in female mice and rats. J Ethnopharmacol 2010; 128: 236-240. 